\title{
Mapping the subsurface structure of the suevite deposit in the north of the Bosumtwi impact crater using electrical resistivity and seismic refraction tomographies
}

\author{
Emmanuel Habimana*,1, Akwasi Acheampong Aning², Vandycke Asare Sarpong2, \\ Sylvester K. Danuor ${ }^{2}$, Callistus Nero ${ }^{2}$ \\ (1) Department of Mining, School of Mining and Geology, College of Science and Technology-University of Rwanda, \\ Kigali, 250, Rwanda. \\ (2) Department of Physics, Kwame Nkrumah University of Science and Technology, Kumasi, Ghana Department of \\ Physics, College of Science, Kwame Nkrumah University of Science and Technology, Kumasi, 00233, Ghana
}

Article history: received May 9, 2018; accepted September 23, 2019

\begin{abstract}
Electrical resistivity imaging and seismic refraction methods have been used to map the subsurface structure of the suevites north of the Bosumtwi impact crater in Ghana to determine the depth extent and in-situ resistivity and P-wave velocity of the suevites. Seven electrical resistivity and two seismic refraction profiles were surveyed. The lengths of the profiles varied between 160 and $600 \mathrm{~m}$. The multi-electrode system was combined with roll along techniques for the resistivity data collection using the gradient array. The data was acquired in 2D where the electrodes separation of $4 \mathrm{~m}$ was the same as the geophones spacing, while the shooting interval was $8 \mathrm{~m}$. The data was processed with Res2DInv and ReflexW for the resistivity and seismic refraction respectively. Electrical resistivity and seismic refraction tomographies identified the suevite deposits which were observed within $12 \mathrm{~m}$ depth. The resistivity of the northern Bosumtwi suevites varies between 1.56 and $25 \Omega \mathrm{m}$, and the P-wave velocity ranges from 3 to $3,9 \mathrm{~km} / \mathrm{s}$. The results also showed that the subsurface is made up of either two or three layers: an unconsolidated topsoil, clayey soil, and fractured claystone. The seismic velocities and the electrical resistivities of the northern Bosumtwi suevites compare very well with those found for suevites at the Ries impact crater Germany and other impact craters.
\end{abstract}

Keywords: Bosumtwi, crater, suevite, resistivity, seismic.

\section{Introduction}

The Bosumtwi impact crater (Figure 1) is an important research site in Ghana. It is one of the world's youngest complex impact craters that was formed by a meteorite impact $1.07 \pm 0.05 \mathrm{Ma}$. The crater which is occupied by Lake Bosumtwi (Figure 1), has an average diameter of $\approx 10.5 \mathrm{~km}$ [W.Jones,1985; Junner,1940]. The lithology of the area 


\section{Emmanuel Habimana et al.}

consists of Proterozoic rocks (2.1 - 2.2 Ma years) of the Birimian Supergroup that consists of lower greenschist facies metasediments, greywackes, schists, quartzites, phyllites, and a minor granitic component [Koeberl, et al., 1997; Leube, et al., 1990; Wright, 1986]. It is situated about $32 \mathrm{~km}$ southeast of Kumasi in the Ashanti Region of Ghana [Reimold, et al., 1998]. The meteorite that caused the Bosumtwi crater was an oblique impactor from the northeast [Aning, et al., 2013b].

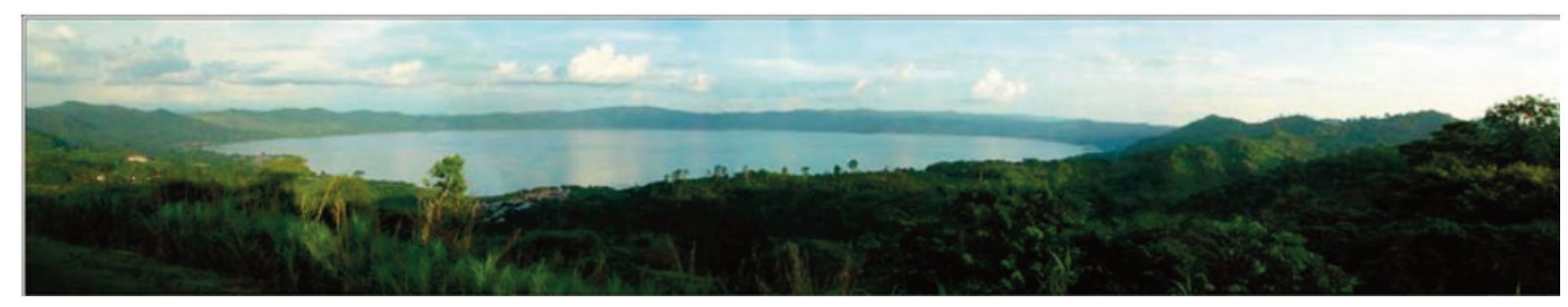

Figure 1. Panoramic view of the Bosumtwi impact crater [Koeberl et al., 2007].

The Bosumtwi suevites are impactites formed from a mixture of melted materials of country rock and meteorites caused by high temperatures and pressures. They have been thrown out and deposited in northern and southwestern parts of the Bosumtwi crater [Koeberl et al., 2007; Reimold et al., 1998]. Stoffler and Grieve [1994] have defined the suevites as polymictic clastic matrix breccia containing glass fragments, rocks, mineral and clasts component of impact melt exhibiting various stages of shock metamorphism. The suevites in the northern part are the interest of this study. The northern Bosumtwi suevites are situated withi $1^{\circ} 235^{\prime}, 1^{\circ} 024 / W$ and $6^{\circ} 332^{\prime}, 6^{\circ} 342^{\prime} N$ about $2.5 \mathrm{~km}$ from the lake shore outside of the rim (Figure 4). The suevites of Bosumtwi impact crater is formed by molten materials of country rock and meteorite, so the detailed study of suevites could reveal the rheology of country rock. In addition, petrography and radiometric dating studies about suevites can prove the chemical composition of the meteorite as well as the age of impact crater. The lithology and subsurface structures of the impact crater can undergo serious modification as a result of shock, heat, and chemical alteration [Pilkington et al., 1992].

The energy of hypervelocity meteorite usually causes different effects on the surface target, such as deformation of the subsurface and the formation of impactites. It also induces physical property contrasts between the lithology of the target rocks and impactites [French et al., 1997; Melosh, 1989]. The origin and composition of a meteorite, brecciation, the fracturing of target rocks and the formation of new rocks as a result of the cratering process cannot be revealed solely based on direct observation. Thus, geophysics and drilling techniques are the most suitable combination to study the consequences of impact cratering process [Pilkington et al., 1992].

Geophysical methods such as seismic, gravity, magnetic, electrical methods etc are all being used to enrich the impact crater science [Campos-Enríquez et al., 2004; Pilkington et al., 1992]. Fracturing, brecciation, and redistribution of target rocks lead to the increase of discontinuities and porosity levels. These effects usually induce resistivity, seismic velocity, density contrasts and other physical properties from the undeformed materials. Therefore, delineating the in situ resistivities of impact structures is useful for understanding the spatial extent modification and distribution of rocks related to impact effects [Tong et al., 2012]. For instance, electrical resistivity was used at Araguainha impact structure to distinguish three different zones: the impact melted rocks, shocked and unshocked sedimentary zones [Tong et al., 2010]. Since the shock induces seismic energy within sedimentary target rocks, seismic refraction technic is important in mapping the depth and horizontal extent of low to highvelocity zones over simple or complex impact craters [Pilkington et al., 1992].

The mapping of the extent of the northern and southwestern Bosumtwi suevite deposits has not been done yet. The previous geological study of the northern suevite deposits was based on localized drilling. To map the depth of the northern suevite deposits, we took 2D electrical resistivity data and complemented it with 2D seismic refraction data. This was done by determining the resistivity and P-wave velocity of the suevites. Knowing the depth of the suevite deposits gives an idea of its thickness which provides additional information and knowledge to enhance the modeling of the crater formation and ejecta deposits.

In this article, the fast, and less expensive, non-invasive electrical resistivity method, complemented with seismic refraction were used to map out the subsurface structure of the suevite deposits by determining the resistivity and 
P wave velocity of suevites. In situ measurements of these physical properties as well as a continuous 2D imaging of suevitic deposits are an additional contribution to the African impact crater science.

Seismic refraction tomography uses first arrival travel times as raw data and is based on inversion techniques to image the subsurface by considering velocity gradient of 2 dimension pixels [Eppelbaum, 2014; Sandmeier, 1998; Wapenaar et al., 2005]. The subsurface deformations and the various strata were also delineated. In addition, the electrical resistivity and the P-wave velocity of the northern Bosumtwi suevites were determined.

In the Bosumtwi impact crater, Plado et al. [2000] revealed generally the difference in physical properties of pre-impact early Proterozoic metasediments (target rocks) and melt-rich suevites (impactites). It was found that the suevites have low densit $\approx 2040 \mathrm{~kg} / \mathrm{m}^{3}$, high porosity $\approx 25 \%$ and high magnetization (magnetic susceptibility $\approx 330 \times 10^{-6}$ relative to the target rocks with density, porosity as well as magnetic susceptibility SI.

Also, a study which was done at the Ries impact crater in Germany by Ernstson (1974), has specifically found that resistivities of suevites range from about. The Chicxulub Scientific Drilling Project (CSDP) found that the ultrasonic $\mathrm{P}$-wave velocity for the suevites in the Chicxulub impact structure (Mexico) ranges from with as mean porosity [Popov et al., 2014]. Additionally, suevites for the Chesapeake Bay impact structure (USA) have P-wave velocities between with aboutas mean porosity [Popov et al., 2014].

\section{Geological background of the Bosumtwi crater area}

The geological stratigraphy around lake Bosumtwi consists of series of supracrustal rock types; namely metasedimentary as well as meta-volcanic rocks, belonging to the 2.1-2.2 Ga Birimian supergroup. Both these sequences are intruded by mostly granitoides [Jones et al., 1981]. The Bosumtwi impact event excavated lower greenschist facies metasediments of the 2.1-2.2 Ga Birimian Supergroup [Jones et al., 1981; Leube et al., 1990]. The lithology of the country rocks that constituted the target rocks are chiefly made of meta-greywackes, shales, and phyllite of the Proterozoic Birimian Supergroup and some intrusion of granitoid [Ferriere et al., 2007; Junner, 1940). There are three types of impact breccias which appear at and around the crater; these are monomict lithic breccia, polymict lithic breccia and also suevites [Boamah and Koeberl, 2003; Reimold et al., 1998]. The suevites dominate the geology of the study area in the northern part of lake Bosumtwi. The Bosumtwi suevites are greyish in color with abundant glass and clasts. They represent a type of ejecta material that contains target lithology in all degrees of shock metamorphism.

They occur as large blocks and as patchy massive deposits which are often covered by thick vegetation and cocoa trees in an area about $1.5 \mathrm{~km}^{2}$ (Figure 2). The large suevite outcrops contain melt inclusions as well as rock fragments (greywacke, shale, granite, phyllite) (Figure 3). From borehole studies, Boamah and Koeberl [2003] generated a geological stratigraphy through the suevite deposits. Thus, the stratigraphic column of BH1 and BH3 (Figure 4) revealed that the thicknesses of the suevites range between $1.5-15 \mathrm{~m}$ and $2-10 \mathrm{~m}$ respectively.
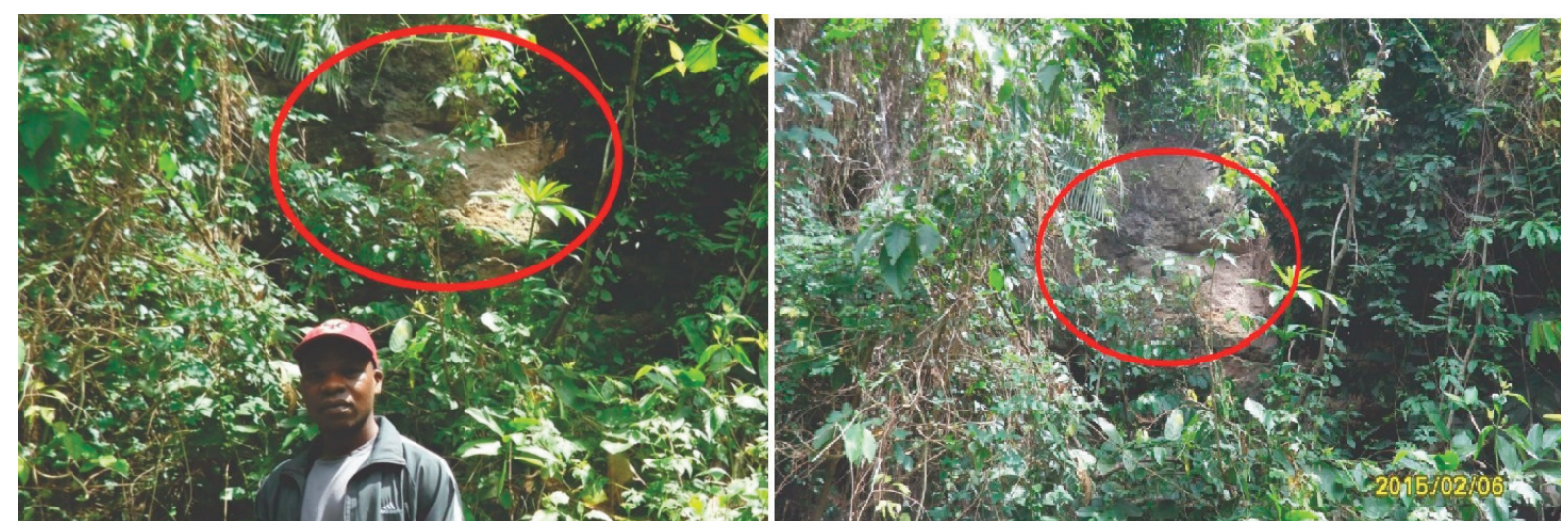

Figure 2. Some suevite outcrops in the study area 
Depth (m) BHl

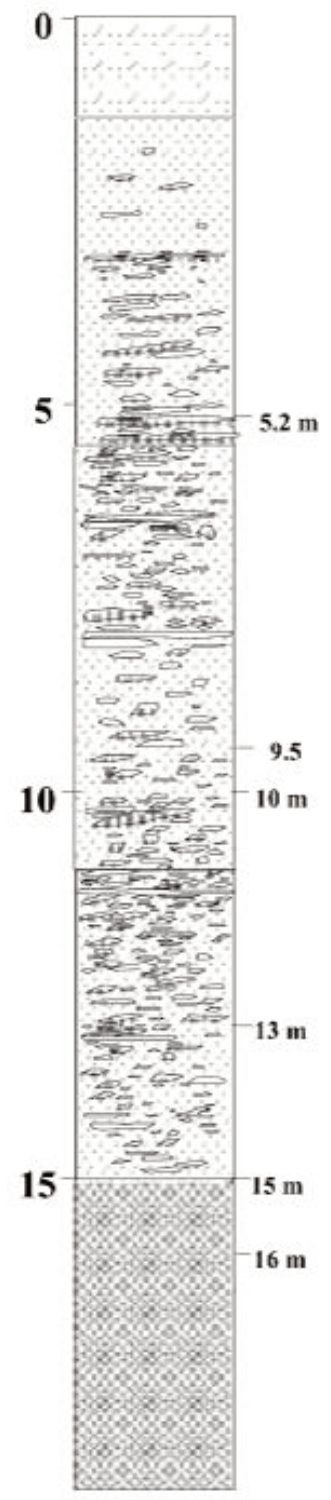

BH3

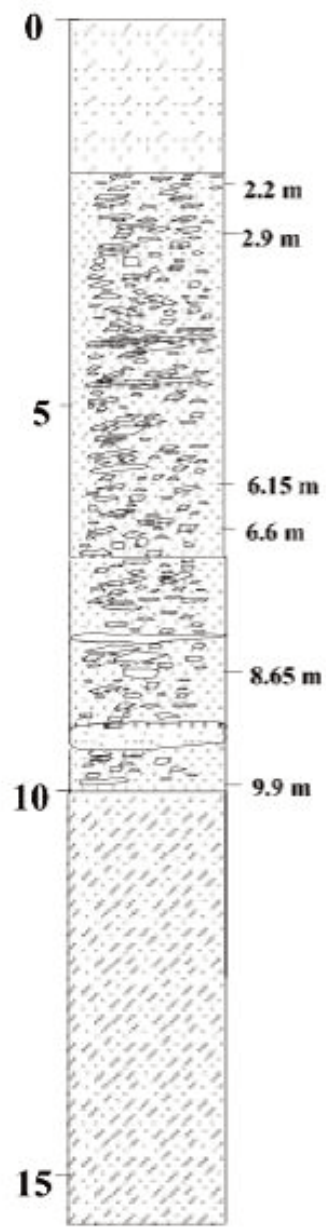

Unconsolidated soil and clay

Fragments of graywacke and phyllite with clay

[IIII Glass melt

Melt showing flow texture

Clast (rocks and minerals)

Matrix

Claystone (highly weathered country rocks)

Figure 3. Stratigraphic column for 2 drilled holes through suevites [Boamah \& Koeberl, 2003].

\section{Data acquisition and processing}

Seven profiles of lengths varying between 160 and $600 \mathrm{~m}$ were surveyed in the northern suevite deposit (Figure 4). Six of them were specifically in suevite deposits whilst one was outside the deposits to serve as a controlled experiment.

\subsection{Electrical Resistivity Survey}

During the resistivity survey, the ABEM LUND resistivity imaging system was employed for data collection. Four multi-core cables and 41 electrodes spaced $4 \mathrm{~m}$ were used for each spread. The gradient array and GRAD 4L8 protocol 

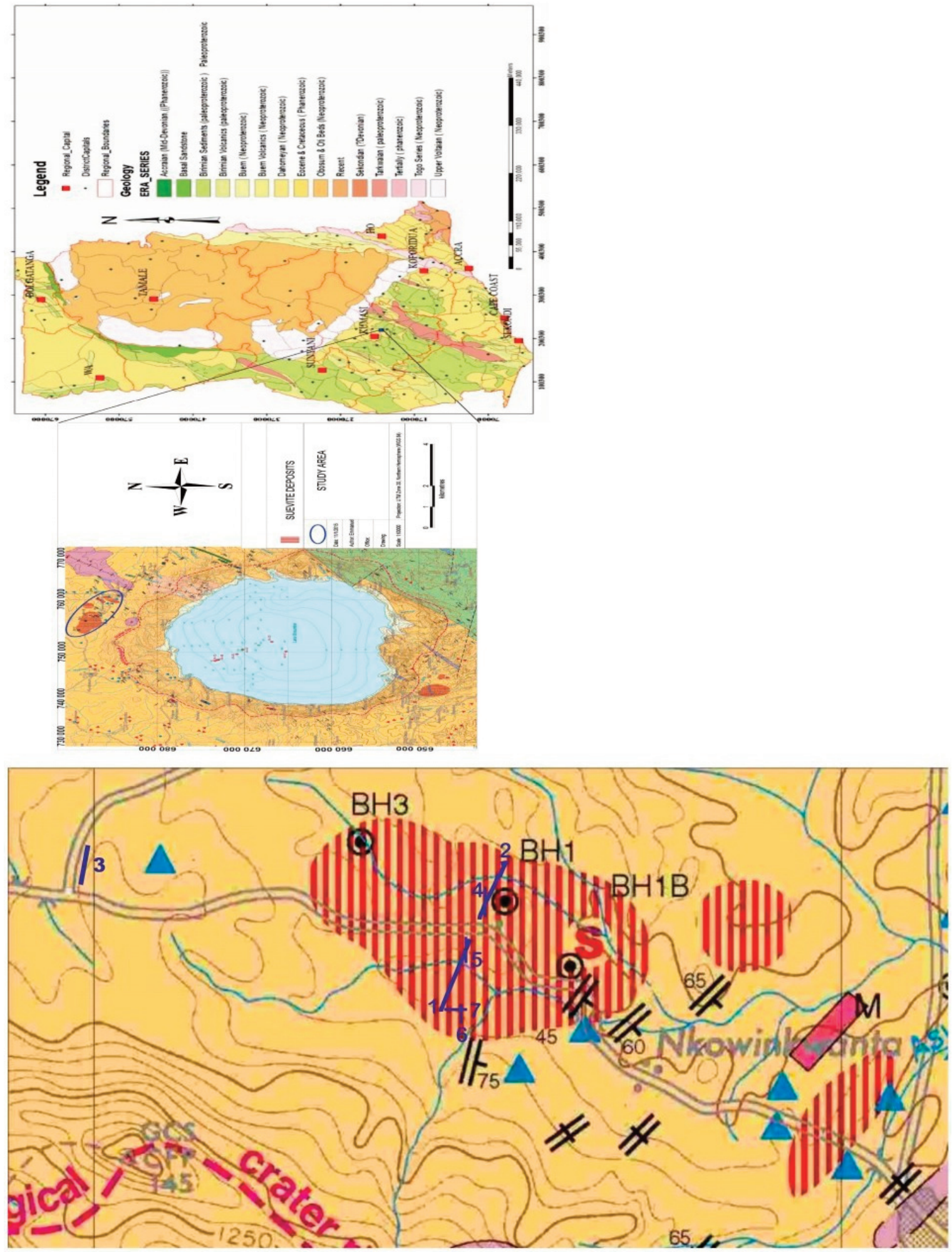

Figure 4. Location of the study area relative to geological map of Ghana, adopted from [Duodu, 2009]. Seven profiles and three boreholes are indicated with blue line color, and black circle respectively.

were then selected to enhance the data density, lateral and vertical resolution during the data acquisition [Aning et al., 2013a; Stummer et al., 2004] Before each measurement, the electrode test was done to ensure that the electrodes were properly connected and planted as well. The computer-controlled multi-electrode system or electrical resistivity tomography (ERT) and roll along survey techniques were combined to scan across the survey line. 


\section{Emmanuel Habimana et al.}

RES2DINV software (www.geotomosoft.com) was used process the data. After removing bad data points, the raw data were inverted based on robust and least squares inversion in order to get the subsurface resistivity distribution that almost fits the measured data. The absolute errors varied between 1.38 to 9.4 . The resistivity model sections underwent 5 to 7 iterations and were displayed with user-defined logarithmic contour intervals. Model sections were displayed including topography where topographic correction was done for each electrode-position.

\subsection{Seismic Refraction Survey}

In this work, a hammer of $6 \mathrm{~kg}$ was used as energy source to cause the vibration of the ground. This nondestructive source was therefore used to deliver 3 consecutive impacts on a rubber plate and the results were stacked. At each shot-position, the trigger geophone was used to trigger a measurement. A spread of two cables was used simultaneously, and 12 geophones of $10 \mathrm{~Hz}$ were vertically planted in series into the ground along each cable with $4 \mathrm{~m}$ spacing making a total distance of $92 \mathrm{~m}$, and $8 \mathrm{~m}$ shooting interval. On each section of $92 \mathrm{~m}$, thirteen inline shot points and one offset point at $4 \mathrm{~m}$ from the first geophone were considered in order to increase the resolution of seismic refraction tomography. The roll-along technique was implemented by overlapping the last two geophones to extend horizontally the area to be covered by the survey (Figure 5).

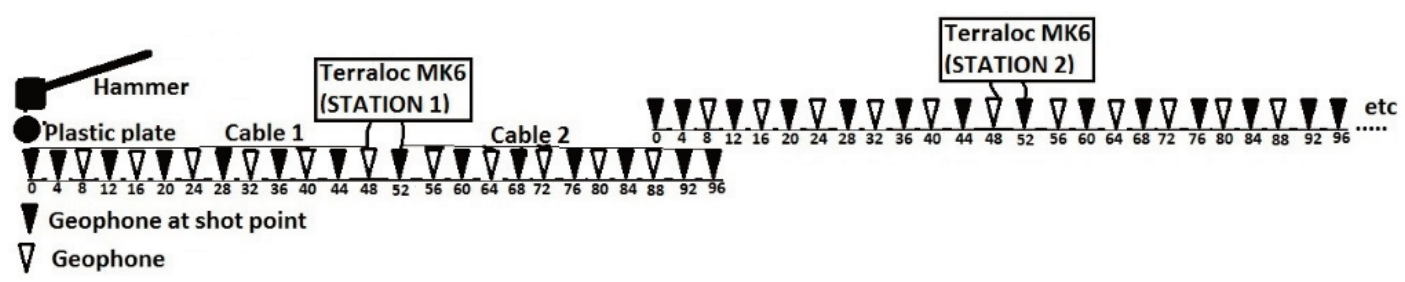

Figure 5. Roll-along technique during seismic refraction survey.

ReflexW software (www.sandmeier-geo.de) was used for processing the seismic data. Processing was done by picking first arrival travel times at first break of wiggles. In travel time analysis, after inserting shot zero travel time of all first arrival seismic traces, layer models were generated. However, as a result of detailed subsurface imaging in terms of vertical and lateral velocity gradient, seismic refraction tomography models were subsequently generated. Before the inversion process, maximum velocity variation of $200 \%$ was used in order to enable strong vertical velocity gradient. Detection of small-scale variation is ensured since space increment of $1 \mathrm{~m}$ was chosen while smoothing value in the horizontal direction was half the shot point spacing $(4 \mathrm{~m})$. Finally, 10 iterations were executed as well as topographic correction for each geophone position.

\section{Results and Discussions}

\subsection{D resistivity and seismic refraction models}

The base-line passed between BH1 and BH3 and consisted of two successive profiles 1 and 2 separated by $14 \mathrm{~m}$, through which is the Asisiriwa Nyameani road. Each profile was about $600 \mathrm{~m}$ long. The electrical resistivity and seismic refraction methods were solely implemented on the base line. Figure 6 (a) shows the resistivity model section of profile 1 which was surveyed from North-East to South-West.

The electrical resistivity tomography of profile 1 shows that the subsurface is formed by 3 layers. The depth of investigation of this profile as well as other electrical profiles was $25 \mathrm{~m}$. Boundary B delineates the top layer thickness which is $\leq 4 \mathrm{~m}$ and has slightly high resistivity values from around $60-400 \Omega \mathrm{m}$. This layer is interpreted to be unconsolidated soil with some moisture content. It is followed by a low resistivity layer of a thickness ranging between 4 and $10 \mathrm{~m}$ which are dominated by clayey soil, as confirmed by Boamah and Koeberl (2003). 


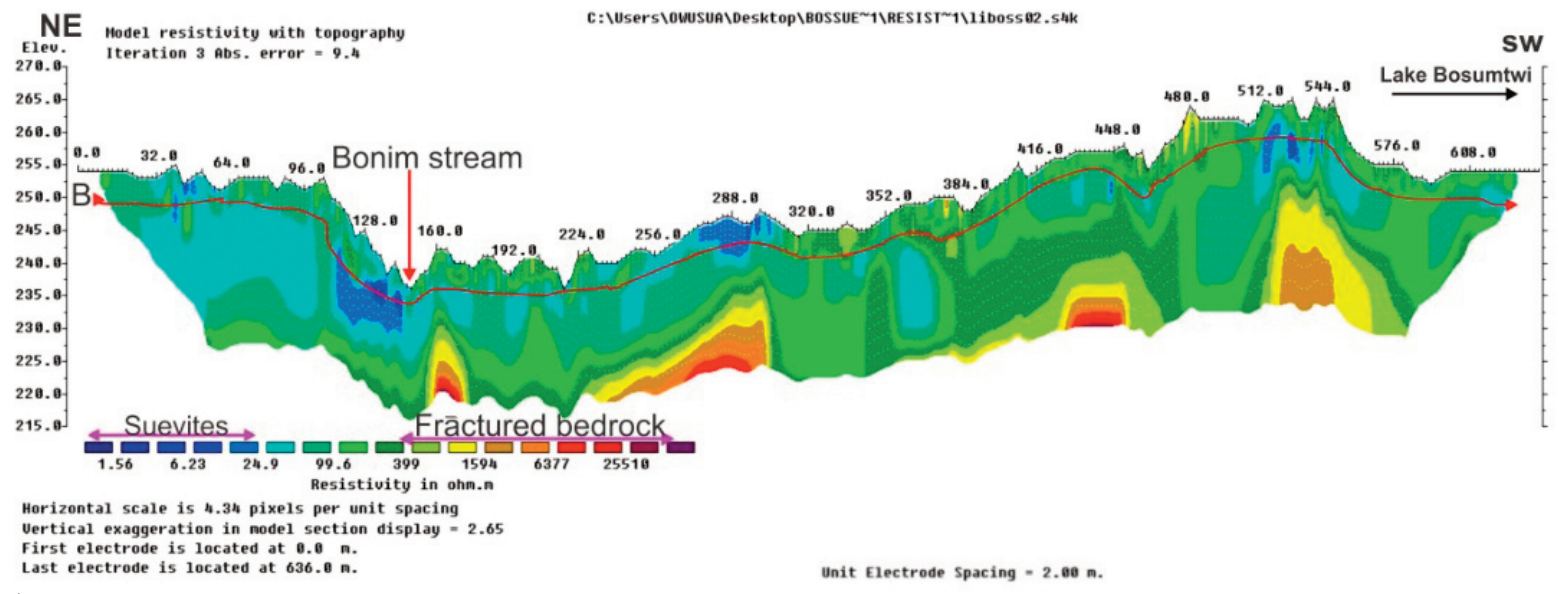

a)
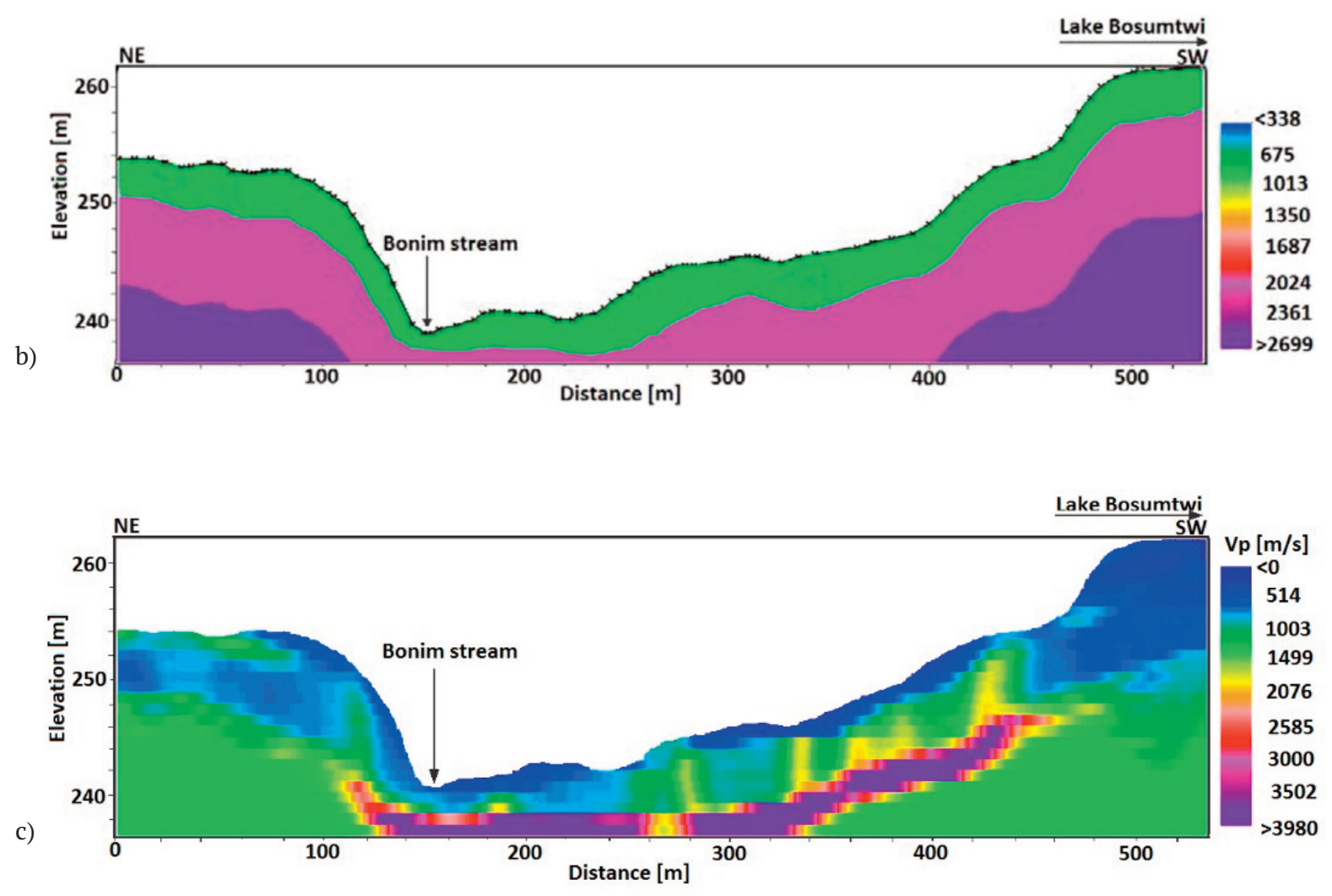

Figure 6. (a) 2D resistivity model section, (b) Seismic layer model, and (c) 2D velocity model of profile1.

At the locations $32-64 m, 128-160 m, 256-320 m$ and $512-544 m$ along the model section, the subsurface is found to have a low resistivity distribution (blue formation) which could represent the suevites. The resistivities range between $1.56-25 \Omega \mathrm{m}$, and they occur at depths $20 \mathrm{~m}$. The suevites are brecciated materials which are more saturated than the surrounding soil.

The highest resistivities of $6000-25000 \Omega \mathrm{m}$, in the third layer start from around $\leq 20 \mathrm{~m}$; it may be a zone of the bedrock of claystone. The resistivity distribution within the basement rock (claystone) is found to be highly changing laterally. This is interpreted to be due to the fractured and shattered basement rocks as a result of the meteorite impact. Fractured claystone zones can be found beyond $10 \mathrm{~m}$ depth, at the locations $170-220 \mathrm{~m}, 300-350 \mathrm{~m}$, and 450 - $500 \mathrm{~m}$ along the model section.

Figure 6 (b) represents the seismic velocity layer model section of profile 1 . The layer model confirm that the subsurface is made up of three layers. The first layer with a thickness $\leq 4$ is characterized by relatively low average 


\section{Emmanuel Habimana et al.}

velocities of $600 \mathrm{~m} / \mathrm{s}$ therefore representing the moist, unconsolidated soils in this layer. The second layer with a velocity of about $2000 \mathrm{~m} / \mathrm{s}$ has a thickness varying from $4-7 \mathrm{~m}$ and is interpreted as clayey soil with some moisture content. The third layer was also delineated with a high velocity of about $2400 \mathrm{~m} / \mathrm{s}$. The lithology of this layer is dominated by consolidated country rocks of claystone similar to the results of the resistivity survey.

The seismic refraction data was further interpreted in terms of tomography in order to know how the lithology of the subsurface is controlling the velocity gradient laterally and vertically. Thus, Figure 6 (c) represents the tomography model section of profile 1 , which revealed a high-velocity contrast $(3000-3900 \mathrm{~m} / \mathrm{s}$ ) within the second layer. It was therefore interpreted as suevite deposits which were found at about $10 \mathrm{~m}$ depth. The high-velocity contrast within tomography models is the result of the suevites which are more saturated than the host sediments.

Figure 7 (a) is the resistivity image of the second profile. It was surveyed from South-West to North-East. It is subdivided into three layers. The first layer of slightly high resistivity values of $60.00-400.00 \Omega m$ represents unconsolidated soil with moisture content. This first layer is delineated by boundary B, where its thickness is $\leq 4 \mathrm{~m}$. It is followed by a zone of the lowest resistivity $1.56-24.00 \Omega m$ that is embedded in the second layer. This zone is interpreted as suevite deposits embedded in a clayey soil. Its thickness varies between 4 and $12 \mathrm{~m}$.

The third layer starts from about $12 \mathrm{~m}$ with high resistivity values ranging from $400-25000 \Omega m$ indicating the presence of a bedrock which is mainly composed of claystone. At depths $\geq 12 \mathrm{~m}$, the resistivity distribution is highly changing laterally; this shows that the basement rock is fractured and shattered. Fractured bedrock zones are imaged below the following distances along the model section: 160 - 200, 280 - $380 \mathrm{~m}$, and 530 - $560 \mathrm{~m}$ of the profile. These findings have good correlations with [Boamah and Koeberl, 2003] results from drill cores of BH1 and BH3. Moreover, the resistivities of the northern Bosumtwi suevites are well correlated with those of the Ries suevites in Germany [Ernstson, 1974; Pilkington et al., 1992].

The seismic refraction was also executed on profile 2. The layer model has also revealed three layers as shown in Figure 7 (b). The first layer has a thickness $\leq 3 \mathrm{~m}$ with a P-wave average velocity of $600 \mathrm{~m} / \mathrm{s}$. It is then followed by a second layer of thickness varying between $4-8 \mathrm{~m}$ with an average velocity of $1900 \mathrm{~m} / \mathrm{s}$. The second layer, therefore, overlies the third layer with a P-wave velocity of $2300 \mathrm{~m} / \mathrm{s}$ velocity. Thus, the low velocity of the first layer of profile 2 represents the presence of unconsolidated soil near the surface. The lithology of the second layer could be formed by clayey soil with little moisture content, while the third layer might be a fractured and shattered country rock of claystone.

The tomography which complements the layer models of profile 2 was further generated. Figure 7 (c) also imaged suevitic distribution within the subsurface. There is also a high-velocity contrast of $3000-3900 \mathrm{~m} / \mathrm{s}$ within the second layer. This high-velocity contrast occurs from the beginning of the profile up to about $380 \mathrm{~m}$ and around the end of the profile. The suevites were found within $10 \mathrm{~m}$ depth. The seismic and resistivity profiles did not cover the entire length extent of the suevite deposits.

The resistivity survey was further carried out along the Nyameani-Boamadumase road from South-West to NorthEast (Figure 8). From the Bosumtwi geological map, this place has no suevites and was therefore chosen for comparison with other profiles which have been carried out in the suevite deposits. The survey was conducted along the road covering a distance of $280 \mathrm{~m}$.

The model section of profile 3 indicates two layers within the subsurface separated by a boundary B; a little highly resistive near-surface is followed by a less resistive layer. The thickness of the high resistivity layer is $12 \mathrm{~m}$ and the resistivity is $>300 \mathrm{~m}$. It is interpreted as dry metasediments comprising phyllite, metagreywackes, shales, and schist. The less resistive layer, whose resistivity is $\leq 300 \Omega m$ could be composed of soils with high moisture content. Since the resistivity model results do not show any less resistive zone near the surface, it reveals that this location does not host suevites. Therefore the resistivity results agree with the geological findings.

Profile 4 has a length of $160 \mathrm{~m}$ and was surveyed heading south (Figure 9). Profiles 4 and 2 cross each other at 16 and $22 \mathrm{~m}$ respectively.

The model section of profile 4 indicates an image of nearly uniform low resistivity $(\leq 300 \Omega m)$ distribution within the subsurface. This probably indicates the presence of clayey soil. The model section does not show any subsurface strata; this means that this profile is likely to be in the same direction as subsurface layers.

In addition to the base-line, profile 5 (Figure 10) was also measured moving southwards. Profiles 5 and 1 cross each other at 20 and $108 \mathrm{~m}$ respectively. The model section of profile 5 does not show a significant difference in resistivity distribution within the subsurface. It could be due to unevenly distribution of clayey soil.

The low resistivity zones around $4 \mathrm{~m}$ depth at the beginning and the end of profile5 were not well resolved. 

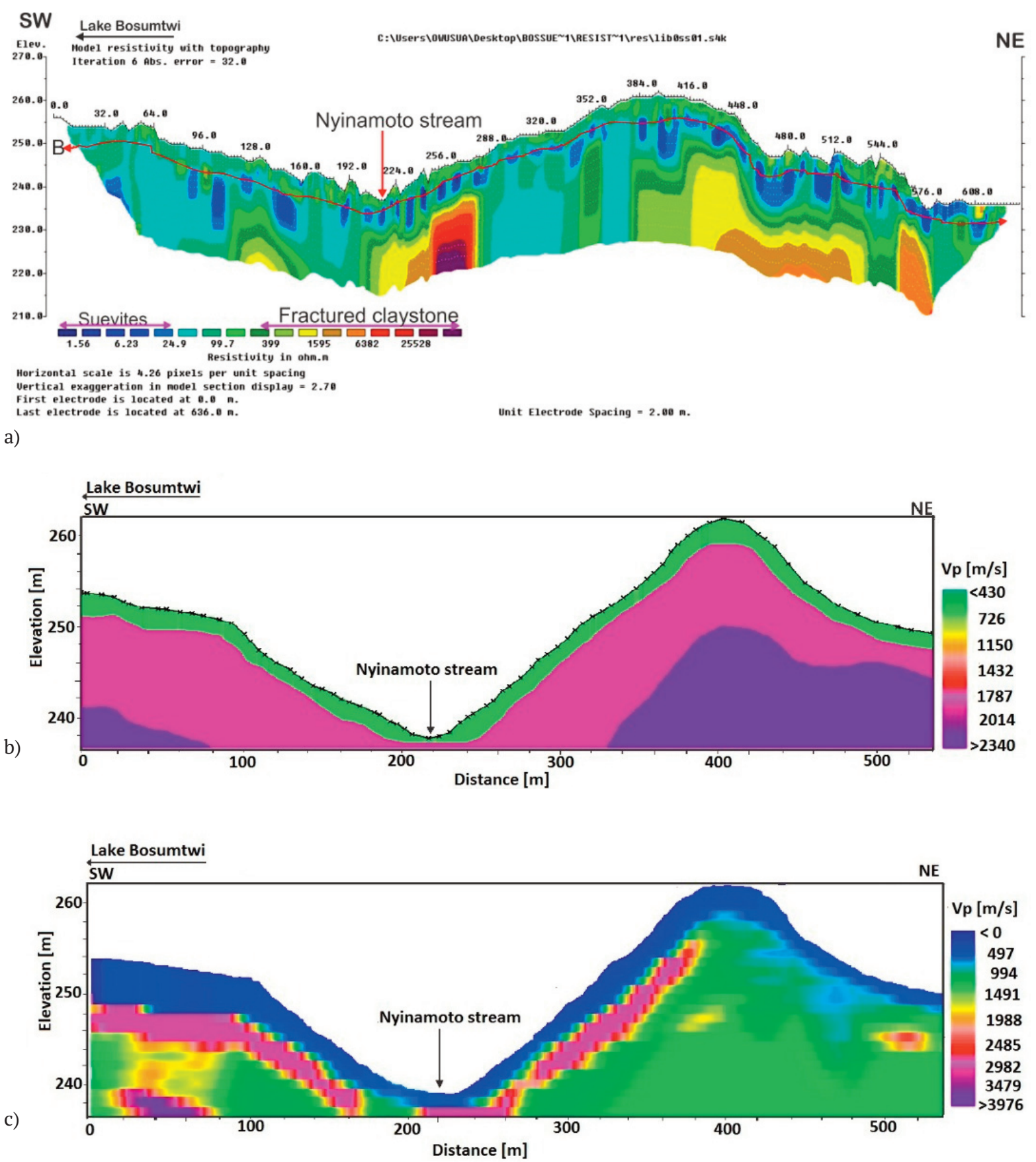

Figure 7. (a) 2D resistivity model section, (b) Seismic layer model, and (c) 2D velocity model of profile 2.

However, the low resistivity area with resistivity $(2-25 \Omega \mathrm{m})$ could be due to the presence of suevites. If this low resistivity area at the base is a suevite deposit, then it will be the deepest suevite deposit found in the Bosumtwi crater area.

The resistivity model section of profile 6 is also $160 \mathrm{~m}$ in length and indicates three layers (Figure 11).

The first layer is slightly resistive due to the dry unconsolidated soil. It is then followed by a less resistive second layer which is likely dominated by clay and moisture towards the end and unevenly intrudes the first layer. The third layer is also slightly resistive; this region could possibly be the fractured claystone bedrock. At the beginning and at the end of the profile around $8 \mathrm{~m}$ depth, there are low resistivity zones $(6-25 \Omega \mathrm{m}$ ), which are likely to be suevite deposits. Profile 7 covers $160 \mathrm{~m}$ and was surveyed westwards (Figure 12). Profiles 6 and 7 cross each other at 100 and 20 m respectively. 


\section{Emmanuel Habimana et al.}

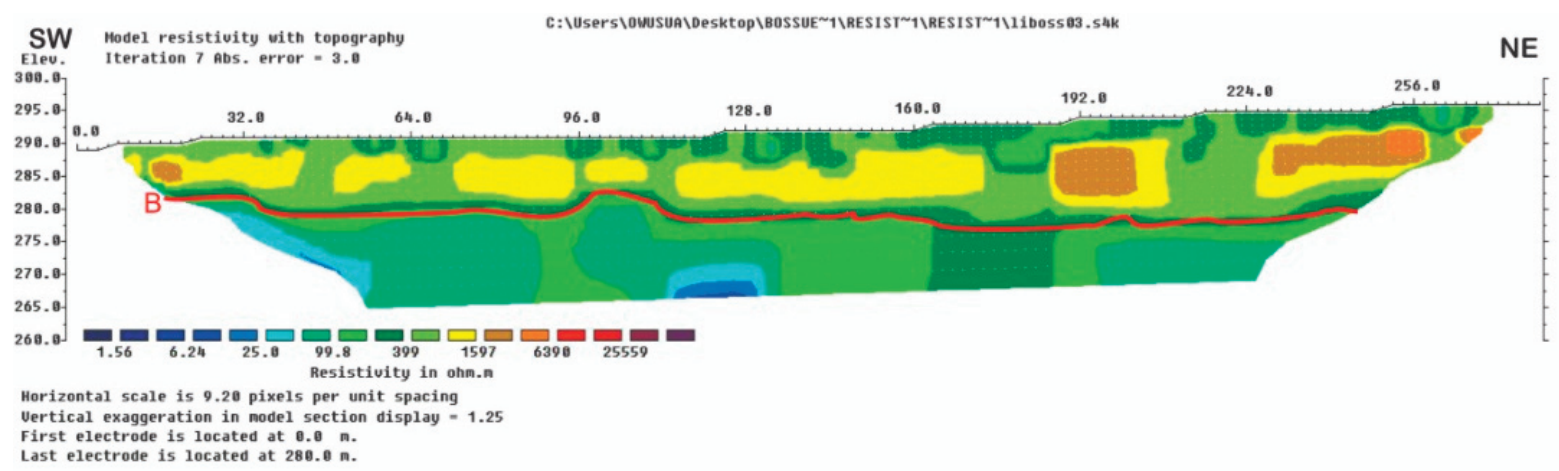

Figure 8. 2D resistivity model section of profile 3.

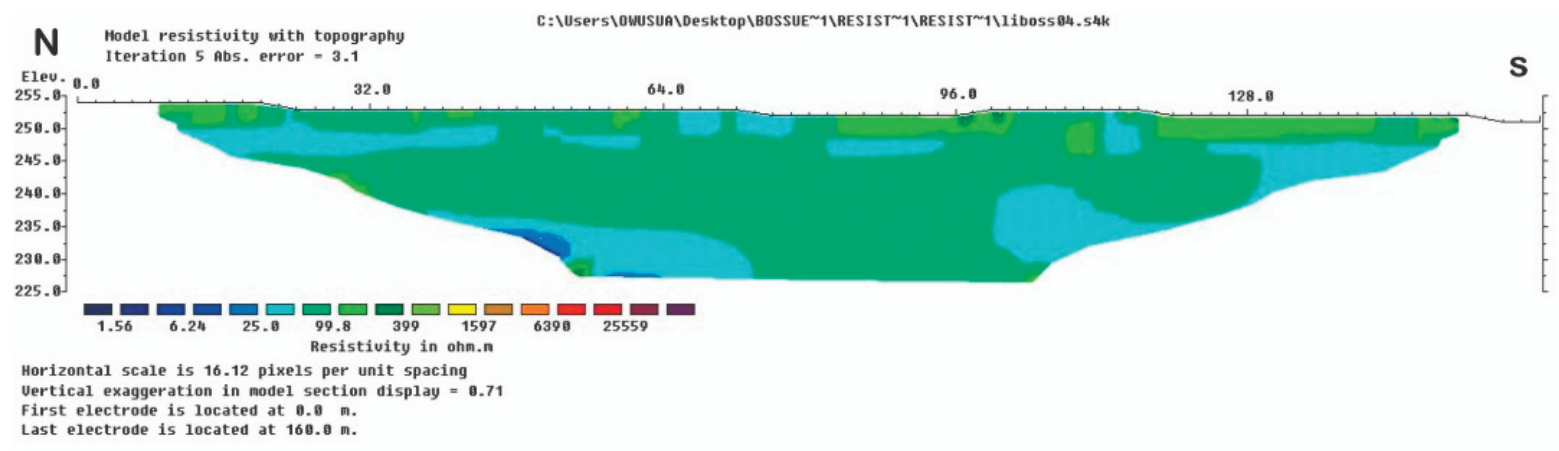

Figure 9. 2D resistivity model section of profile 4 .

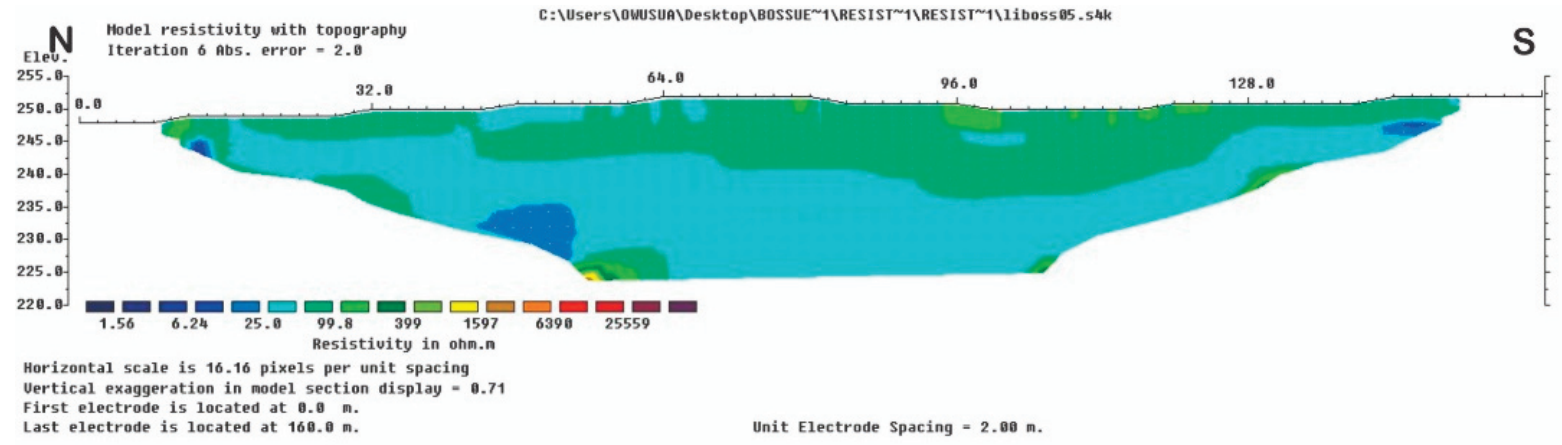

Figure 10. 2D resistivity model section of profile 5 .

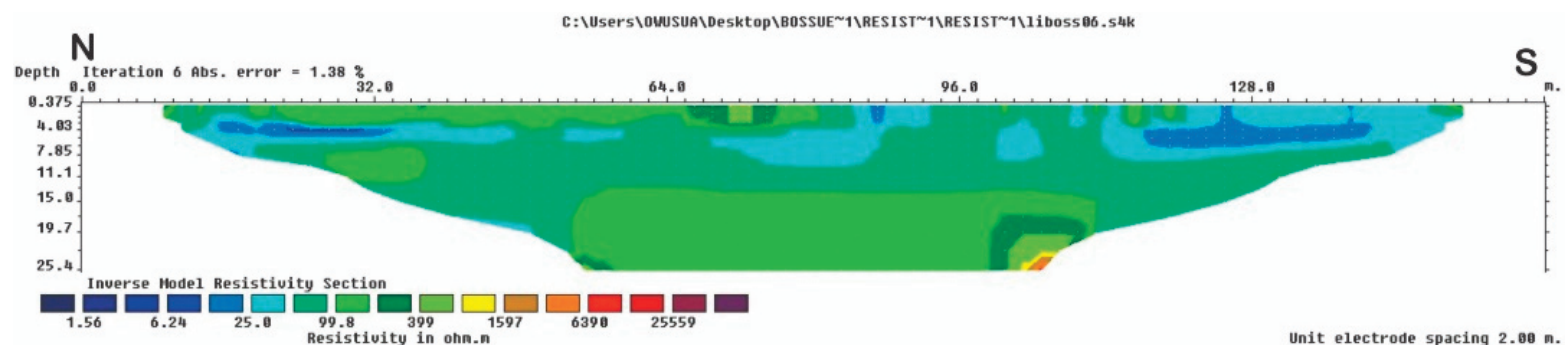

Figure 11.2D resistivity model section of profile 6 . 


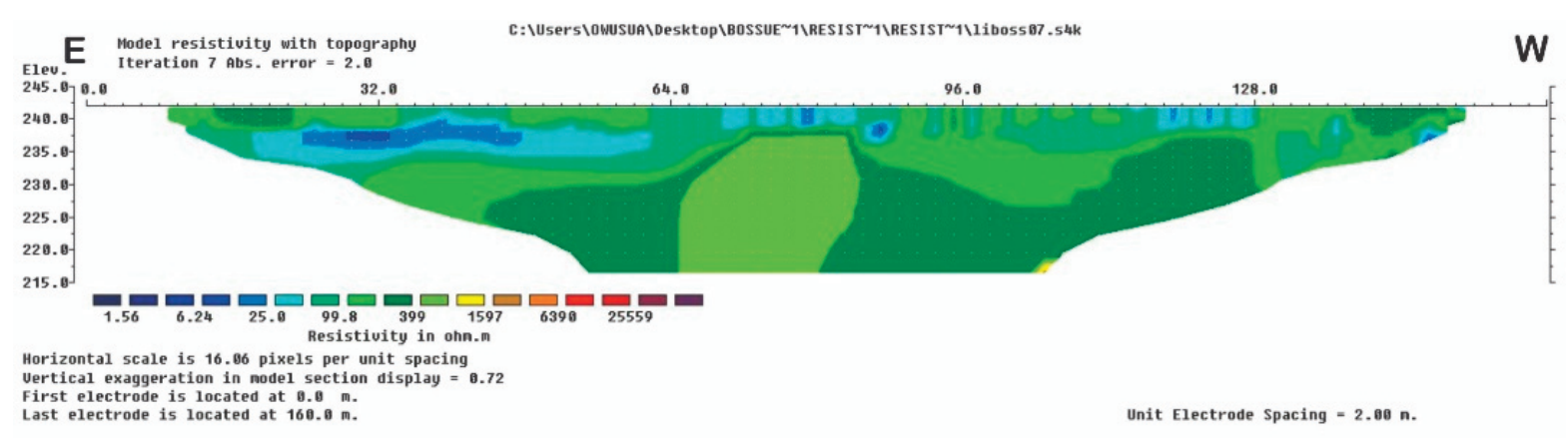

Figure 12. 2D resistivity model section of profile 7 .

The model section, Figure 12, shows that the subsurface is formed by two layers. The first layer is less resistive, with a resistivity value less than $300 \Omega \mathrm{m}$. It is a result of unconsolidated soil with some amount of moisture. The second layer with slightly high resistivity between 300 and $1000 \Omega \mathrm{m}$ starts from about $15 \mathrm{~m}$ depth. This layer could represent fractured claystone containing some moisture. At the crossing point of profiles 6 and 7 (around $32 \mathrm{~m}$ along profile 7$)$, there is a low resistivity zone $(6-25 \Omega m)$ which could be suevite deposits.

\section{Conclusion}

The seismic refraction and electrical resistivity results showed the suevite deposits and mapped out the subsurface strata as well as the fractured zones. Suevite deposits were found at depths $\leq 12 \mathrm{~m}$ with a low resistivity range of 1.56 - $25 \Omega \mathrm{m}$ along all the profiles.

Generally, three layers were identified on the baseline; the top layer with slightly high resistivity (60 - $400 \Omega m$ ) has a thickness $\leq 4 \mathrm{~m}$. It was found that this resistivity is controlled by unconsolidated soil and moist clay. The low resistivity regions $\leq 25 \Omega m$ which are mostly dominated by suevite deposits embedded in clayey soils was observed in the second layer of profiles 1 and 2 . The very high and varying resistivities $(6000-25000 \Omega m)$ were found in the third layer of both profiles beyond $12 \mathrm{~m}$ depth. The high resistivity is the result of the bedrock of claystone, while the lateral variation is controlled by fractured zones. Fractured zones were identified in the third layer of the resistivity model sections with slightly low resistivity.

Two layers were mapped out for profiles 3, 4, 5 and 6 whilst profile 7 was a three-layer model. Profile 3 was outside the demarcated suevites area and no suevites deposits were found on its resistivity model section.

The seismic refraction also delineated 3 layers of the subsurface and mapped out the suevite deposits. The nearsurface layer with thickness $\leq 4 \mathrm{~m}$ has a P-wave velocity of about $600 \mathrm{~m} / \mathrm{s}$. The thickness of the second layer varies from 4 - $8 \mathrm{~m}$ and the P-wave velocity varies between 1900 and $2000 \mathrm{~m} / \mathrm{s}$. This second layer is dominated by clayey soils. The third layer can be found beneath $12 \mathrm{~m}$ depth. Its P-wave velocity varies from 2300 to $2400 \mathrm{~m} / \mathrm{s}$. It represents a fractured and shattered basement of claystone.

The high-velocity contrast, $3000-3900 \mathrm{~m} / \mathrm{s}$ that was observed in the tomography model could be as a result of the suevite deposits and was found at depths $\leq 10 \mathrm{~m}$. The resistivity and P-wave velocity values of northern Bosumtwi suevites are in good correlation with an ultrasonic P-wave velocity of suevites in Chicxulub impact structure (Mexico) and Chesapeake Bay impact structure (USA) [Ernstson, 1974; Popov et al., 2014]. The study area of this project is covered by cocoa trees, and the surface is covered by cocoa leaves; thus, evaporation of the subsurface water is limited. Therefore, the suevites are likely characterized by saturated pores.

Acknowledgements. We would like to acknowledge the University Rwanda-College of Science and Technology that provided Mr. Habimana a study leave. We thank the Physics Department of the Kwame Nkrumah University of Science and Technology, Kumasi, Ghana for providing the field equipment and software. 


\section{Emmanuel Habimana et al.}

\section{References}

Aning, A., P. Tucholka and S. Danuor, (2013a). 2D Electrical Resistivity Tomography (ERT) survey using the multielectrode gradient array at the bosumtwi impact crater, Ghana. J. Environ. Earth Sci., 3(5), 12-27.

Aning, A., P. Tucholka, and S. Danuor, (2013b). The Bosumtwi Meteorite Impact Crater, Ghana: New results on the impact direction of the meteorite from 2D Electrical Resistivity Tomography (ERT) survey. Intl. Res. J. Geol. Min., 3(4), 147-157.

Boamah, D. and C. Koeberl, (2003). Geology and geochemistry of shallow drill cores from the Bosumtwi impact structure, Ghana. Meteor. Planet. Sci., 38(8), 1137-1159.

Campos-Enríquez, J. O., F. J. Chávez-García, H. Cruz, J. G. Acosta-Chang, T. Matsui, J. Arzate, A., M. J. Unsworth, J. Ramos-López, J. (2004). Shallow crustal structure of Chicxulub impact crater imaged with seismic, gravity and magnetotelluric data: Inferences about the central uplift. Geophys. J. Intl, 157(2), 515-525; https://doi.org/10.1111/j.1365-246X.2004.02243.x

Duodu, J. A. (2009). Geological Map of Ghana 1: 1000 000. Geological Survey Department.

Eppelbaum, L. (2014). Estimating informational content in geophysical observations on example of searching economic minerals in azerbaijan. Izv. Acad. Sci.Azerb. Rep., Earth Sciences, 3-4.

Ernstson, K. (1974). Structure of Ries crater from geoelectric depth soundings. Journal of Geophys.-Zeitschrift Geophys., 40(5), 639-659.

Ferriere, L., C. Koeberl and W. U. Reimold, (2007). Drill core LB-08A, Bosumtwi impact structure, Ghana: Petrographic and shock metamorphic studies of material from the central uplift. Meteor. Planet. Sci., 42(4-5), 611-633.

French, B., C. Koeberl, , I. Gilmour, S. Shirley, J. Dons and J .Naterstad (1997). The gardnos impact structure, norway: Petrology and geochemistry of target rocks and impactites. Geochimica et Cosmochimica Acta, 61(4), 873-904.

Jones, W. (1985). Chemical analyses of Bosumtwi Rater target rocks compared with the Ivory Coast tektites. Geochimica et Cosmochimica Acta, 49(12), 2569-2576.

Jones, W. B., M. Bacon and D. A. Hastings (1981). The Lake Bosumtwi Impact Crater, Ghana. Geol. Soc. Am. Bull., 92(6), 342-349.

Junner, N. (1940). Geology of the Gold Coast and Western Togoland with revised geological map. Published under the Authority of His Excellency Sir Arnold Hodson, Governor of the Gold Coast.

Koeberl, C., R. Bottomley, B. P. Glass and D. Storzer (1997). Geochemistry and age of Ivory Coast tektites and microtektites. Geochimica et Cosmochimica Acta, 61(8), 1745-1772.

Koeberl, C., B. Milkereit, J. T. Overpeck, C. A. Scholz, P. Y.O. Amoako, D. Boamah, S. Danour, T. Karp, J. Kueck, R.E. Hecky, J. W. King, J. A. Peck (2007). An international and multidisciplinary drilling project into a young complex impact structure: The 2004 ICDP Bosumtwi Crater Drilling Project-an overview. Meteor. Planet. Sci., 42:483511., 42, 483-511.

Leube, A., W. Hirdes, R. Mauer and G. O. Kesse (1990). The early Proterozoic Birimian Supergroup of Ghana and some aspects of its associated gold mineralization. Precambrian Res., 46(1), 139-165.

Melosh, H. J. (1989). Impact cratering: A geologic process. Research supported by NASA. New York, Oxford University Press (Oxford Monographs on Geology and Geophysics, No. 11), 1989, 253, 1.

Pilkington, M. and R. A. F. Grieve, (1992). The Geophysical Siganture of Terrestrial Impact Craters, Rev. Geophys., 30, 2, 161-181.

Plado, J., L. Pesonen, C. Koeberl and S. Elo (2000). The Bosumtwi meteorite impact structure, Ghana. A Magnetic Model. Meteor. Planet. Sci., 35, 723-732.

Popov, Y., S. Mayr, R. Romushkevich, H. Burkhardt and H. Wilhelm (2014). Comparison of petrophysical properties of impactites for four meteoritic impact structures. Meteor. Planet. Sci., 49(5), 896-920.

Reimold, W. U., D. Brandt and C. Koeberl (1998). Detailed structural analysis of the rim of a large, complex impact crater: Bosumtwi Crater, Ghana. Geology, 26(6), 543-546.

Sandmeier, K. (1998). Reflexw. Program for the processing of seismic, acoustic or electromagnetic reflection, refraction and transmission data. Karlsruhe, Germany: Sandmeir Software.

Stoffler, D., R. and Grieve (1994). Classification and nomenclature of impact metamorphic rocks: A proposal to the IUGS subcommission on the systematics of metamorphic rocks. In Lunar and Planetary Science Conference, $25,1347$.

Stummer, P., H. Maurer and A.G. Green (2004). Experimental design: Electrical resistivity data sets that provide 
optimum subsurface information. Geophys., 69(1), 120-139.

Tong, C. H., V. R. Elis, C. Lana, and Y. R. Marangoni (2012). Electrical Imaging of Impact Structures. Surv. Geophys., 33(5), 861-868; https://doi.org/10.1007/s10712-012-9178-y

Tong, C. H., C. Lana, , Y. R. Marangoni and V. R. Elis (2010). Geoelectric evidence for centripetal resurge of impact melt and breccias over central uplift of Araguainha impact structure. Geology, 38(1), 91-94; https://doi.org/10.1130/G30459.1

Wapenaar, K., R.Ghose, G.Toxopeus, and Fokkema, J. (2005). The wavelet transform as a tool for geophysical data integration. Integrated Computer-Aided Engineering, 12(1), 5-23.

Wright, J. B. (1986). Geology and mineral resources of West Africa. Springer Science and Business Media.

"CORRESPONDING AUTHOR: Emmanuel HABIMANA,

Department of Mining, School of Mining and Geology, College of Science and Technology-University of Rwanda,

Kigali, 250, Rwanda;

e-mail: enzabarusha@gmail.com

MPhil in Geophysics,

research field: Subsurface studies using Geo-electrics and Seismic methods

(c) 2020 the Istituto Nazionale di Geofisica e Vulcanologia.

All rights reserved 